\title{
Biodiversity and Poverty Alleviation in Nigeria
}

\section{Addy Jose Vershima ${ }^{1^{*}}$, Kabough Jonathan Terkimbi ${ }^{2}$, Aliyu Ibrahim ${ }^{3}$, Mohammed K. Haruna ${ }^{4}$}

\author{
1 Department of Biological Sciences, P.M.B. 2373, University of Agriculture, Makurdi, Nigeria \\ ${ }^{2}$ Federal Capital Territory Administration, Abuja Nigeria. \\ ${ }^{3}$ Department of Science Laboratory Technology, Nassarawa State Polytechnic, Lafia, Nigeria \\ ${ }^{4}$ Department of Farming System Research, Lake Chad Research Institute, Maiduguri, Nigeria \\ "E-mail address: joseaddy1@gmail.com
}

Keywords: biodiversity; alleviate; poverty; Nigeria

\begin{abstract}
Biodiversity provides essential services like provision of food, medicine, pest and disease control, pollination, protection from natural hazards, regulation of climate and air quality, nutrient recycling, cultural and aesthetic values and source of income. Due to the neglect of agriculture, there is massive poverty in Nigeria. Conservation of biodiversity would alleviate poverty through sustainable agriculture. In order to conserve biodiversity while reducing poverty and increasing human well-being and development to achieve MDGs, biodiversity must become part of government development policies.
\end{abstract}

\section{INTRODUCTION}

The Millennium Development Goals (MDGs) is a United Nations initiative launched in 2000 and adopted by UN member states in 2001 under the auspices of the United Nations Development Programs (UNDP) to improve the lot of humanity by 2015. Nigeria is a member of that international effort and so much money and personnel at state and federal levels have been deployed to achieve the (MDGs) by 2015 (UN/MDGs Report, 2009).

The eight MDGS formulated by UN Heads of State for achievement in 2015 includes the eradication of extreme poverty and hunger, achieving universal primary education, promotion of gender equality and empowering women; reducing child mortality; improving maternal health; combating HIV/AIDS, malaria and other diseases; ensuring environmental sustainability ; and developing global partnership for development (UN/MDGs Report, 2009).

According to an Annual Report produced by United Nations Economic Commission for Africa (ECA) and the UNDP on progress in Africa toward the Millennium Development Goals, Africa as a region has not shared in the global success in reducing poverty even though average income in the region has risen. Some countries such as Ghana and North Africa countries are making progress on poverty reduction. The Report explained further that a significant proportion of the poor in Africa are chronically poor, meaning that it will require much more efforts to lift them out of poverty.

In 2014, real GDP was projected to grow by $6.2 \%$ based on an outlook of increased agricultural production, stimulation of the non-oil sectors, and robust fiscal and monetary policies. The real GDP growth rate as reported by the National Bureau of Statistics (NBS) in the first, second and third quarters of 2014 was $6.21 \%, 6.54 \%$ and $6.23 \%$ respectively (www.pwc.com.ng, 2015).

In 2015, hunger continues to persist in Nigeria. Nonetheless, efforts need to be scaled up to meet this target because of its interaction with other MDGs. This paper therefore, examines the roles of biodiversity in reducing extreme poverty and hunger in Nigeria. 


\section{BIODIVERSITY IN NIGERIA}

Nigeria is located on latitude $10^{\circ} \mathrm{N}$ and longitude $8^{\circ} \mathrm{E}$ within the Equator and tropic of Cancer with total area of 923,768 square kilometres. Nigeria is rich in biodiversity because the country is endowed with a variety of plants and animal species (Nigeria $1^{\text {st }}$ National Biodiversity Report, 2001). Biodiversity encompasses the variability of all organisms from all sources and the ecological complexes of which they are part of. This includes all life forms (fauna and flora). There are about 7895 plant species identified in 338 families and 2,215 genera. There are 22,000 vertebrates and invertebrates species. These species include about 20,000 insects, about 1000 birds, about 1,000 fishes, 247 mammals and 123 reptiles. Of these animals; $0.14 \%$ is threatened while $0.22 \%$ is endangered. About 1.489 species of micro organisms have also been identified. All species occur in different vegetation that range from the mangrove in the south to the Sahel in the north (Nigeria $1^{\text {st }}$ National Biodiversity Report, 2001). It has also been reported that Nigeria's present network of protected areas include 28 Game reserves (NFNBR, 2001).

\section{IMPORTANCE OF BIODIVERSITY}

\subsection{Food provision and food security}

Crops rely on pollination to turn out the food to human and other animals. Although some plants are wind pollinated, most plants are dependent on insects and other animals for pollination. Bee species collectively pollinate 250,000 known angiosperm species. Wild animals like leopard, crocodile and antelope are hunted for their meat and eggs. Proteins and other nutrients are mostly supplied through these forest animals, fishes and birds providing up to $70 \%$ of their protein diet (Emma et al., 2010).

\subsection{Medicine}

An estimated $80 \%$ of people in less developed countries depend on traditional medicine for primary health care. Some 120 chemicals extracted in pure form from around 90 species of plants are used for medicine throughout the world (Kate and Laird, 1999).

\subsection{Pest and Disease Control in Agricultural Systems}

Biodiversity also enhances natural pest control mechanisms in the agro ecosystem. Increasing diversity of trees and other plants will increase the number of insects' predators such as birds, lizards and certain insects so as to improve pest control. The beneficial of the biological control agents include substantial increase in crop yields, large reduction in mite populations, and environmental benefits due to the non-use of persistent chemical insecticides (Pedigo, 1995).

\subsection{Protection from Natural Hazards}

Mangroves protect coastal areas from erosion, and storms. In the Savanna, trees (shelter belts) serve as wind breakers. They serve as micro-climatic buffer around concrete urban heat islands (EEA, 2009c).

\subsection{Leisure, cultural and aesthetic value}

Many people derive pleasure from biodiversity through leisure activities such as hiking, bird watching, photographing or natural history study. Many tourists prefer to see and interact with wild species in their habitat. Tourism has the potentials to generate significant foreign exchange earnings, employment and investment towards economic development (Ovat and Okey, 2003).

\subsection{Regulation of Climate and Air Quality}

Forests of multiple species are more resilient to climate change and their ecosystem service of temperature control under their canopy help modulate the rise (Intergovernmental Panel on Climate change, 2010). Forests help to store carbon (iv) oxide, protect water sheds and provide habitats tom terrestrial animals (Food and Agricultural Organization, 2003).

\subsection{Sources of income}

More than 3 billion people depend on marine and coastal biodiversity for their livelihoods particularly in developing countries where fishing is a main subsistence and commercial activity 
(Convention on Biodiversity, 2008). Forests are vital national and regional economies through revenue and employment provided by the forestry sector (FAO, 2003).

\subsection{Waste Recycling}

With the growing unemployment, hunger, and poverty particularly in urban areas of developing countries, waste may provide a short to medium term trade -off through reuse and recycling activities (FAO, 2003). Waste recycling offers ample opportunities for poverty alleviation and job creation. Such opportunities already exist in Nigeria.

\section{POVERTY IN NIGERIA}

Poverty means the "state of having little or no money and few or no material possessions" (worldnet.princeton.edu/per/webwn, 2000). The incidence of poverty in Nigeria is an agenda that leaves no room for doubt. Indeed, all successive governments in Nigeria have made appreciable efforts to alleviate poverty such as operation feed the nation(OFN), green revolution, national directorate of employment; national poverty eradication program (NAPEP), family economic advancement programme (FEAP). Huge sums of the country's income have been spent to finance programs that will tackle the menace of poverty in Nigeria (Maduagwu, 2005; Agalamanyi, 2006). Despite several attempts to alleviate poverty, none has materialized thus leading to poor wretched and deprived more ever. Seventy percent $(70 \%)$ of the population live less than 1 dollar per day (Federal Republic of Nigeria, 2000).

The following factors have been identified as being responsible for the failure of poverty alleviation programs in Nigeria:

- corruption

- inconsistency in policy implementation

- bad leadership

- rapid population growth and

- Lack of sound agricultural policy and protracted neglect of the agricultural sector of the economy (Agalamaanyi, 2006).

\section{ROLE OF BIODIVERSITY IN POVERTY ALLEVIATION}

Biodiversity can play its role in poverty alleviation through sustainable agriculture. Sustainable agriculture (FAO, 2003) is an integrated system of plant and animal production practices having a site-specific application that will over the long term:

a) Satisfy human needs for food and fiber

b) Enhance environmental quality and the natural resources base upon which the agricultural economy depends.

c) Sustain the economic viability of farm operations and

d) Enhance the quality of the life for farmers and society as a whole. These goals may be achieved by the following strategies:

\subsection{Integrated Pest Management (IPM)}

This is a comprehensive approach that uses a combined means to reduce the status of pests to tolerable levels while maintaining a quality environment (Pedigo, 1995). IPM should be made a national policy by the federal government for farmers to adopt it.

\subsection{Creation of World Heritage Site}

Most parks and reserves should setup to protect spectacular animals or endangered plants and habitats. Many areas are "hotspots" for agro-biodiversity and thus warrant better conservation and management in their own rights. 


\subsection{Mass Awareness and People Participation in Biodiversity Conservation}

Most awareness programs should be taken up in safeguarding existing wilderness, parks and biological reserves for future improvements in agriculture. Abuses such as deforestation and over hunting of game animals in these parks should be avoided to prevent extinction. For example by creating mass awareness on culturing threatened species of fishes, the fish farmer can play an important role in the fishes in natural water bodies.

\subsection{Cultural approach to Biodiversity Conservation}

Some cultural activities such as non-burning, minimum tillage and the use of natural fertilizers and mulching should be encouraged.

Improved forest management through reduced impact logging to increase sequestration and reduction in emission also help to reduces losses of biodiversity.

\subsection{Research Strategy}

There should be greater investment in research to improve the quality of information on the relationship between land use and biodiversity benefit. The research strategy must integrate the physical, economic, social and cultural condition of the farmers so as to come up with innovations and technologies that conserve and sustain biodiversity. This will involve an inter-disciplinary research team made up of socio-economic and biological scientists as well farmers all working toward a common goal of biodiversity conservation and sustainability.

\subsection{Market oriented approach to Biodiversity Conservation}

There is need to find market for lesser known crops. His will ignite interest by growers of such endangered species to increase its productivity. The search for planting material might have varieties that would have been abandoned, for example, sesame "benniseed" production. Markets are constantly changing and new opportunities are emerging for tapping some of these dwindling pockets of agro-biodiversity to generate income for local people.

\section{CONCLUSION}

Nigeria is richly endowed with diverse flora and fauna. Government has adopted the policy of integrated conservation and sustainable use of the nation's biological diversity, with a view to promoting greater awareness of the value of biodiversity.

Due to the neglect of agriculture, there is mass poverty in Nigeria. Conservation of agriculture will alleviate poverty through sustainable agriculture and the consideration of biodiversity impacts (both negative and positive) in shaping of policies, programs and projects, with strategic environment assessment. The drastic fall of crude oil -Nigeria main source of economy from the international market will worsen the economy and thus increase the poverty level in the country. Again what Nigeria requires is enhanced cooperation at the local, regional and global levels to ensure biodiversity conservation, equitable sharing of the benefits derivable from these resources in order to alleviate poverty.

\section{Acknowledgement}

The author acknowledges the immense contribution of Prof., Amali, Okwoli of Biological Sciences University of Agriculture, Makurdi-Nigeria 


\section{References}

[1] Agalamanyi, C.U.. Major causes of massive poverty in Nigeria. An Analysis of some Federal Government Poverty Alleviation Initiatives Journal of Nigeria Government and polities 1. (2006) 26-29

[2] Convention on Biological Diversity The value of Nature: Ecological, Economic, Cultural and Social benefits of Protected Areas, available at http:/www.cbd.int/doc/publications/cbd-valuenature-en-pdf (2008). Accessed 5th March, 2015

[3] EEA. Ensuring quality of life Europe's cities and towns. Tackling the environmental challenges by European and global change. EEA Report No. 5/2009 European Environmental Agency, Copenhagen. Available at: http://www.eea.europa.eu/publications/quality-of-life-in Europe-citiesand towns. Accessed $5^{\text {th }}$ March, 2015

[4] Emma, O, Ibeawuchi I, and Chinenye L, Biodiversity conservation for sustainable agriculture in tropical rainforest of Nigeria. New York Science Journal 2 (7) (2010) 81-87

[5] Food and Agricultural Organization, Trends in the oceanic captures and clustering of large marine ecosystems-2 studies based on the FAO technical paper 435, (2003) 1-71

[6] Federal Republic of Nigeria, Nigeria Poverty Reduction Plan, Federal Ministry of Finance, Abuja, Nigeria.(2000) 12-14

[7] Intergovernmental Panel on Climate Change, report at http://www.ipcc.ch/ (2010) Accessed $24^{\text {th }}$ February, 2015

[8] Kate, K and laird S.A, The commercial use of biodiversity. Earth scan publication Plc http://www,sciencepub.net/researcher (1999) Accessed 4th February, 2015

[9] Maduagwu, T. 2005. Alleviating Poverty in Nigeria. http://www.afbis.com/analysis/alleviatingpoverty.html (2005) Accessed 21st February, 2015

[10] Nigeria First Biodiversity Report (2001) 185-186

[11] Ovat O. and Okey, Tourism and economic development in Nigeria: An Empirical Investigation, Global Journal of Social Services. 2(1) (2003) 33-34

[12] Pedigo, L.P., Entomology and Pest Management. New York Macmilian Pub.Co. (1995) 8-10

[13] www.pwc.com/nigeriataxblog, Nigeria Budget 2015: Fiscal and macroeconomic analyses Accessed $9^{\text {th }}$ March, 2015

[14] United Nation, The Millennium Development Goals Report 2009, available at http://www.un.org/millenniumgoals/pdf/MDG_report_2009_Eng.pdf Accessed $4^{\text {th }}$ March, 2015

[15] Worldnet.princeton.edu/per/webwn http:/www.google.coza/search/hl=en define poverty and sa=glossary definition. (2000) Accessed $11^{\text {th }}$ January, 2015 